\title{
Ethnobotanical Study of Edible Plant Communities on the Slopes of Mount Merapi and Merbabu, Indonesia
}

\author{
Lita Ayu Umartani*, Maizer Said Nahdi** \\ Department of Biology, Faculty of Science and Technology, Universitas Islam Negeri Sunan Kalijaga Yogyakarta \\ Jl. Marsda Adisucipto No.1 Yogyakarta 55281, Tel. + 62-274-540971, Fax. + 62-274-519739, Indonesia \\ Corresponding author \\ ayulita1998@gmail.com*, maizer.nahdi@uin-suka.ac.id**
}

Manuscript received: 09 April, 2021. Revision accepted: 13 July, 2021. Published: 19 July, 2021.

\begin{abstract}
Ethnobotany is a study of the interaction between local people and their natural environment, especially regarding the use of plants as food and medicinal ingredients. Edible plants are a daily basic need whose existence is a necessity for the people on the slopes of Mount Merapi and Merbabu. How to use plants is transferred from generation to generation to form a culture. The research was carried out in March-May 2020 with the aim of digging local knowledge about plants used as food, including staple food, vegetables and medicines by studying the species diversity, including the benefits of plant parts, habit, how to use, process and how to obtain these species. The data were collected by using a combination of qualitative and quantitative methods with in-depth interviews through 40 respondents who were selected by purposive sampling. The results showed that the communities on the slopes of Mount Merapi and Merbabu used 74 plant species from 37 families as food sources. The favorite family is Fabaceae, followed by Zingiberaceae and Solanaceae. The most widely used habitus of plants were herbs (36.49\%), followed by bush (28.38\%), shrubs (18.92\%) and trees (16.22\%). Plant parts that are widely used are leaves $(29.73 \%)$, fruit $(17.57 \%)$, tubers $(10.81 \%)$, seeds $(9.46 \%)$, roots, rhizomes and flowers $(6.76 \%)$, shoots $(5.40 \%)$, stems $(2.70 \%)$ and water, skin and heartwood $(1.35 \%)$. The most common ways to use it are eaten raw as vegetables $(29.73 \%)$, boiled $(16.22 \%)$ and drink (12.16\%). How to obtain it are through own cultivation (72.97\%), and buying at the market (21.62\%). The highest use values were Adas (Foeniculum vulgare Mill.) (0.25), chili pepper (Capsicum annum L.) (0.20), turmeric (Curcuma dosmetica loir) and water spinach (Ipomoea aquatica Forsk.) (0.17). The highest importance values were rice (Oryza sativa L.) (5.23\%), and fennel (Foeniculum vulgare Mill.) (4.57\%).
\end{abstract}

Keywords: Culture; Ethnobotany; in-depth interviews; Rice (Oryza sativa L.); Mount Merapi; Mount Merbabu.

\section{INTRODUCTION}

The existence of plants is a pleasure and a blessing given by Allah SWT to his creatures in interacting and managing nature. Humans are given a mandate from Allah, namely first, Allah allows humans to take and make the best use of natural products, humans are required to be able to take lessons from natural phenomena and events that occur. Humans are required to maintain and maintain environmental sustainability (Zuhdi, 2012). Ethnobotany is a study of the interaction between local communities and their natural environment, especially regarding the use of plants in their daily life (Martin, 1998). These uses can be in the form of plants as food and medicine.

The demand for food has undergone a shift from being very dependent on nature, switched to unhealthy fast food (Anggraini, 2013). Some people nowadays are starting to realize the importance of healthy living by trying to consume foods that have physiological effects to the body to get maximum health (Astawan, 2003). Based on the Food Law (UU) number 18 of 2012, food is anything that comes from biological sources intended for human consumption that has certain functions to the body, used for medicinal purposes and as daily food (Hariyani, 2013).

Each region has a specific plant use system and differs from other regions according to the diversity of plants in its environment. This includes the use of food on the slopes of Mount Merapi and Merbabu to support human life. The area is well-known as a center for producing green vegetables with a majority of the population of farmers, besides that the area also has high enough rainfall causing the soil to become fertile and the abundance of plants and has a high variance. Edible plants in the area are used by the community as medicinal plants, food as well as traditional ceremonies used in everyday life. How to use plants by the community is obtained and has been carried out from generation to generation to form a culture (Gunawan, 2014).

Advances in science and technology as well as the increase in the level of public education are very influential in the knowledge of the younger generation 
of the culture that has been formed in society. One such knowledge is the use of the diversity of edible plants, resulting in this knowledge being increasingly marginalized, even though so far little has been stated in writing. Based on this, a comprehensive research is needed to answer the problems that arise, namely how the community's knowledge of the use of food plants on the slopes of Mount Merapi and Merbabu, precisely in Mliwis Village, Cepogo, Boyolali on plants that are used as food, including use as staple food, vegetables and medicine by specifically studying the diversity of species, including plant parts, habits, their use, processing methods and how to obtain these species.

\section{MATERIALS AND METHODS}

\section{Research Period and Location}

The research was carried out on the slopes of Mount Merapi and Merbabu, mainly in Mliwis Village, Cepogo District, Boyolali Regency, covering 2 hamlets, namely Baksari and Ngarsapura (Figure 1). The reason for choosing the two locations was because these two hamlets were the centers of agricultural and food production in the Boyolali area. The research began in March - May 2020. Mliwis is located at 110 "22" - 110 "50" East Longitude and 7 "36" - 7 "71" LS.

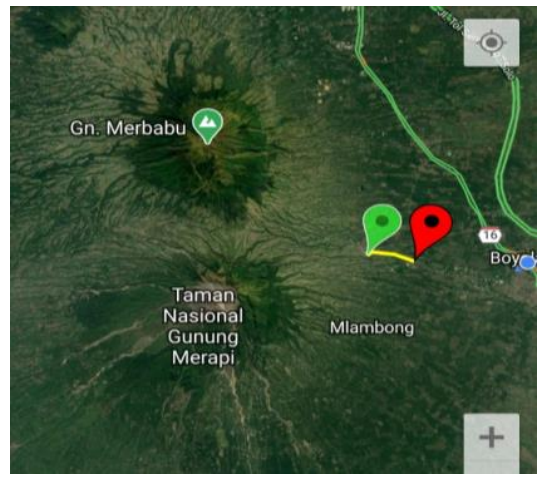

\section{Information:}

- Ngarsapura

Paksari

Figure 1. Research locations on the slopes of Mount Merapi and Merbabu, in the hamlets of Baksari and Ngarsapura.

\section{Data Collection}

Data collected by all edible plants that have been used by the people on the slopes of Mount Merapi and Merbabu including staple food, vegetables, medicines including species, plant parts, habits and methods of use. This information was obtained with the help of 40 respondents who were selected by purposive sampling with a total of $10 \%$ of the number of households (heads of households) in the study location.

Collecting data on communities consisting of traditional, local, vegetable farmers, vegetable sellers, herbalist sellers and other users through in-depth interviews through open questionnaires to be analyzed descriptively, qualitatively, and quantitatively. Plants found were identified using the book Flora of Java volume I (1963), volume II (1965), and volume III (1968) by Backer and van der Brink Jr., and Indonesian Useful Plants by Heyne (1987). Meanwhile, quantitative data are used for botanical data collection, including inventory and identification of plants used by the community as food plants.

The benefit value data uses a modified formula from Cotton (1996) and Nahdi and Ardyan et al., (2019), as follows:

1. Use Value

$$
\mathrm{UV}_{\mathrm{s}}=\frac{\varepsilon U V i s}{i s}
$$

Information:

UVs : total number of use values of a type $s$

UVis : total value of type s given by the informant $i$

is : total number of informants interviewed for the type s use value

2. Important Value

Importance value index calculation using a formula

$$
\mathrm{IV}=\frac{N i}{{ }_{N}} \times 100 \%
$$

Information:

$$
\begin{array}{ll}
\mathrm{IV} & \text { : important value } \\
\mathrm{Ni} & \text { : number of respondents using type A } \\
\mathrm{N} & \text { : total number of respondents }
\end{array}
$$

\section{The Profile of Respondents}

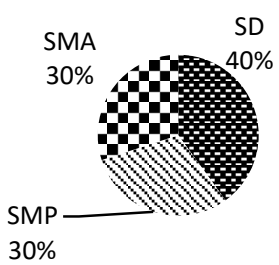

A



B

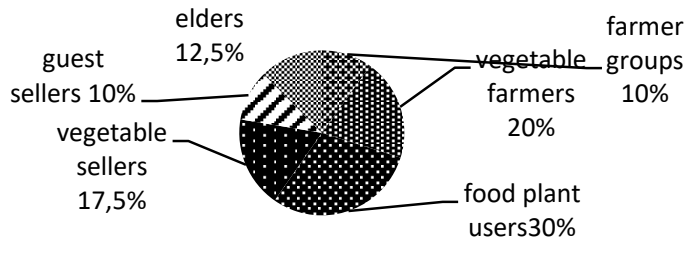

C

Figure 2. The profile of the respondents in the studied area based on: A. Education; B. Gender; C. employment.

Respondents are considered as representatives of the people on the slopes of Mount Merapi and Merbabu, represented by the Mliwis community as users of edible plants. They were selected from various profiles of gender, educational level and occupation. The percentage of female respondents are higher than male 
respondents (60\% and $40 \%$ respectively). Based on the level of education, $40 \%$ of them are only elementary school (SD) graduates, 30\% junior high school (SMP) graduates, and 30\% junior high school (SMA) graduate. According to occupations include vegetable farmers
(20\%), vegetable sellers $(17.5 \%)$, elders $(12.5 \%)$, farmer groups (10\%), guest sellers (10\%) and food plant users $(30 \%)$. Meanwhile, according to gender $60 \%$ of them are women, and $40 \%$ are men (Figure 2).

\section{RESULTS AND DISCUSSION}

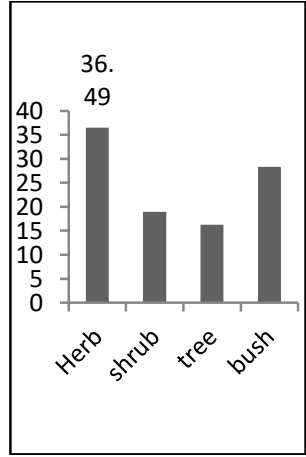

A

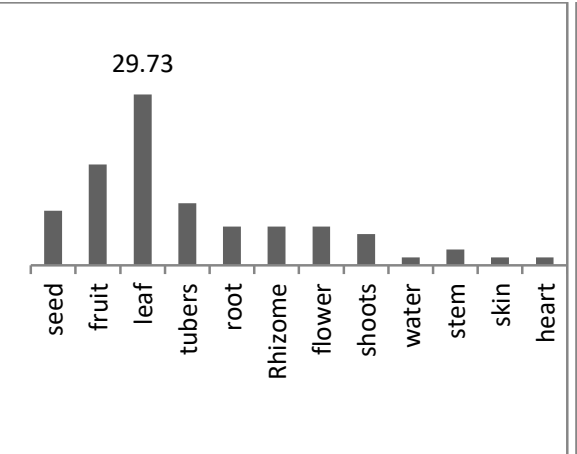

B

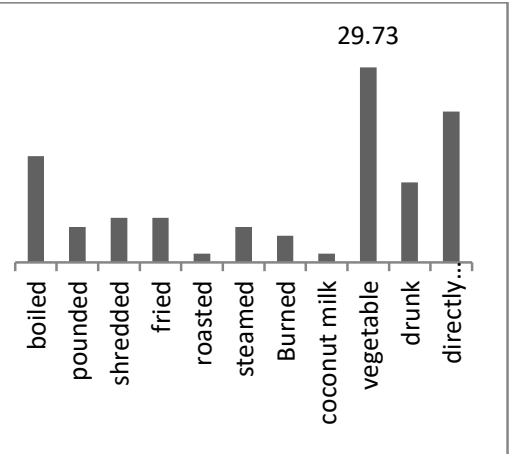

C

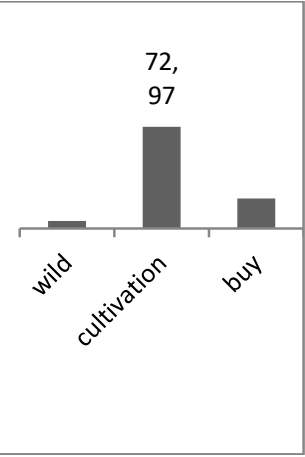

D

Figure 3. The summary of information on the use of edible plants based on: A. Habitus; B. The part of the plant being used; C. How to use; D. The locations where the plants being collected.

The diversity of edible plants. Based on the results of the research, the people on the slopes of Mount Merapi and Merbabu use 74 species of food plants from 37 families (Table 1) with details, Baksari Village has 64 plant species as food used by the community and Ngarsapura Village has 59 species from 40 respondents. The same number of species found in the two hamlets is used by the community either as daily staples, vegetables or medicine. The number of food and medicinal plant species in this study is more than the research conducted by Nita (2017) in the Arfak tribe, namely 29 species of edible plants and 16 species of medicinal plants. This is because the use of edible and medicinal plants by local communities is different from one region to another.

Some of the factors that influence it are the efficacy and availability, language, social relations, cultural history, understanding, local beliefs and beliefs (Silalahi, et al., 2018). Usually, food and medicinal plants that are easily available with sufficient availability will be more used by the community. However, Gudro, et al., (2014) stated another reason, where the factors that influence the use of plants by the community is the purpose of their use.

The food plants, most widely used by the people on the slopes of Mount Merapi and Merbabu come from the Fabaceae family, which is used as a vegetable, followed by the Zingiberaceae family as a cooking and medicinal spice. Meanwhile, there are fewer types of plants from other families. Previous research conducted by Zulharman (2015) in the Sambori tribe, Bima, East Nusa Tenggara showed the same results, namely the Fabaceae family is the family most widely used by the community as food.

Based on the results of interviews with respondents, the main reason for the higher use of plants of the Fabaceae family is that these families are easily found in gardens, yards and in markets for sale. Zulharman (2015) adds, the Fabaceae family is widely used by the community because it is easy to cultivate and does not really need specific soil. In addition, according to Permana et al., (2011) that almost every community has unique local wisdom as an adaptation to the environment and food in the form of fruit, vegetables and medicinal.

Plant habitus used as food. The results showed that there were four habitus of plants that were used by the community as food ingredients, namely trees, shrubs, shrubs and herbs. Herbs are the most widely used habits habitus with a percentage of $36.49 \%$ of 74 species, followed by bush $(28.38 \%)$, shrubs $(18.92 \%)$ and trees $(16.22 \%)$. The results of research conducted by Nita (2012) in the Arfak tribe, Manokwari Regency, Sukmawati, et al., (2013) in Toga Village, Central Sulawesi and Nahdih, et al., (2016) in the Turgo area, Yogyakarta showed the same results, namely the majority of herbal habitus are the habitus most widely used by people as raw material for food and medicine with varying percentages.

The reason the people of the slopes on Mount Merapi and Merbabu use more of the herb and bush habitus as food plants compared to others, which is easy to obtain and has highly adapted to the environment so that the growth rate and development are very fast and easy to 
grow in various locations besides that there is no need for proper cultivation specifically (Sukamto, 2007).

The part of food plants. Based on the results of the study, some people use food plants using plant parts or organs for consumption, which can be grouped into twelve (12) types of organs. Leaves occupied the top position with the most percentage $(29.73 \%)$, followed by fruit $(17.57 \%)$, tubers $(10.81 \%)$, seeds $(9.46 \%)$, roots, rhizomes and flowers, respectively $(6.76 \%)$, shoots $(5.40 \%)$, stems $(2.70 \%)$ and the last position was occupied by water, skin and heart, respectively $(1.35 \%)$ (Figure 3.B). Sukmawati, et al., (2013) in the Kaili Rai tribe also showed the same thing, namely that people use more leaf parts than other parts with a percentage of $47.36 \%$ of 46 species. The same thing also happened in the research by Nahdi, et al., (2016) that leaves were the highest part that was used by the community with a percentage of $51.39 \%$.

Based on the results of interviews, favorite leaves are used because they are easy to obtain, there are always many leaves in one plant and easy to produce, so that people use them more than other parts, beside-leaves also contain various substances needed by the body. According to Payung, et al., (2016) the high utilization of leaves is because the leaves are used almost every day for vegetables and spices. Apart from leaves, fruit and tubers are also parts that are widely used, because both are places to store food reserves that contain carbohydrates and other substances that are beneficial to the body (Savitri, 2008).

The serving method of food plants. Based on the way it is used, people use food plants in eleven ways: boiling, pounding, grated, fried, roasted, steamed, roasted, coconut milk, vegetable, drunk and immediately consumed. The most widely used method by the community is by using vegetables with a percentage of $29.73 \%$. The reason for the high processing method using vegetables is because people generally consume it as a complement to rice in their daily lives, it is easy to process, besides that people are also aware of their health and the many substances contained in plants that are very beneficial for the body. According to Teo (2001) vegetables are a source of vitamins, minerals and phytochemicals that contain dietary fiber which is good for health.

In contrast to research conducted by Efremila, et al (2015) by drinking directly is the most common way, because beside being practical, cost-effective, it can also react directly in the body both for food and internal medicine.

The source of food plants. The people on the slopes of Mount Merapi and Merbabu obtain food plants by taking plants that come from wild plants, self-cultivating products, and buying at the market with details that the most widely used methods is self-cultivation $(72.97 \%)$ (Figure 3.D) compared to plants illegal (5.4\%) and buying in the market $(21.62 \%)$. This is because the cultivation process is very simple, namely by using the empty land around the house or garden using makeshift tools. Generally, land in yards and gardens is used by the community to grow vegetable plants so that it is easy to collect them without having to travel long and cheap distances. In addition, medicinal plants are usually used as spices in cooking. In contrast to Zaman's research, et al (2013), the people of Sumenep district, East Java mostly uses wildly obtained plants because of their economic value without spending money to get them.

The way to get the second most widely used food plant by the community is buying at the market (21.62\%) because food plants are the main and important need for the local community, and are an easy and practical way without carrying out the planting and harvesting process which requires time quite long and usually carried out by landless communities. Meanwhile, how to obtain it by taking wild plants is very little due to the lack of public knowledge of the potential of these plants.

Value Benefits (Uvs) and Important Value (INP). Based on the research results, the food plants that had the highest use value were fennel species (Foeniculum vulgare Mill.) With a value of 0.25 , followed by chili pepper (Capsicum annum L.) with a value of 0.20 , and turmeric (Curcuma dosmetica loir) and water spinach (Ipomoea aquatica Forsk.) With a value of 0.17 (Table $1)$.

Several types of food plants above, are already well known among the surrounding community because in addition to being used for daily food they also have many benefits to cure various diseases, fennel (Foeniculum vulgare Mill.) In addition to plants that are unique and favored by the surrounding community, are also a plant that has many medicinal benefits. According to (Kurniawan, et al., 2015), fennel can treat diseases such as itching, coughing and motion sickness. The essential oil content in fennel has anethol and estragole compounds as antipyretics (Newall et al., 1995).

The highest importance value based on the research results was Padi (Oryza sativa L.) with a value of $5.23 \%$, followed by fennel (Foeniculum vulgare Mill.) $4.57 \%$, and cassava $(3.27 \%$ ) (Table 1). The important value of these two plants is not too far apart, so it can be said that both of them are excellent plants and are typical of the people of the slopes on Mount Merapi and Merbabu. It is said so because at the beginning of the interview with respondents almost all of them mentioned these plants. Regardless of the plant's content, the community's use of plants as a source of food and medicine is only based on hereditary knowledge and personal experience without knowing its contents. People make use of plants based on knowledge obtained from their parents or elders.

Based on the use value (UVs) and important value (INP), it is not always the plants that have the highest use value also have the highest importance value. This is 
because the use value only looks at how many benefits a species has, while the important value is seen not only in terms of benefits, but how much people use these plants, so that even if the benefits are not as many as other species, these plants trusted and idolized by the community.

Table 1. List of Edible Plants Used by the Community of village of Baksari and Ngarsapura, Boyolali.

\begin{tabular}{|c|c|c|c|c|c|}
\hline Family & Scientific Name & Local Name & Benefits & Uvs & INP \\
\hline Amaranthaceae & Amaranthus tricolor $\mathrm{L}$. & Bayem Cabut & detoxify body toxins & 0,12 & 1,96 \\
\hline Anacardiaceae & Mangifera indica $\mathrm{L}$. & Pelem & cure anemia & 0,1 & 1,31 \\
\hline \multirow[t]{3}{*}{ Apiaceae } & Foeniculum vulgare Mill. & Adas & overcome menstrual disorders, cure fever & 0,25 & 4,57 \\
\hline & Daucus carota L. & Wortel & Improve eye health, & 0,1 & 2,61 \\
\hline & Apium graveolens L. & Ledri & Anti inflammatory & 0,07 & 1,31 \\
\hline \multirow[t]{3}{*}{ Araceae } & Colocasia esculenta L. & Tales & Overcoming heart disease & 0,07 & 0,65 \\
\hline & Xanthosoma sagittifolium $\mathrm{L}$. & Kimpul & Overcoming digestive problems, & 0,07 & 0,65 \\
\hline & Amorphophallus paeoniifolius & Suweg & Anti-poison, treat wounds & 0,07 & 2,61 \\
\hline Arecaceae & Cocos nucifera L. & Kelopo & Neutralizing body toxins & 0,1 & 1,96 \\
\hline \multirow[t]{2}{*}{ Asteraceae } & Tagetes arecta L. & Ningkir & treat ulcer disease & 0,1 & 0,01 \\
\hline & Lactuca sativa $\mathrm{L}$. & Selada & Maintain eye health & 0,07 & 0,01 \\
\hline Bombaceae & Durio zibethinus L. & Duren & fight infection (antibacterial) & 0,05 & 1,96 \\
\hline \multirow[t]{4}{*}{ Brassicaceae } & Brassica rapa $\mathrm{L}$. & Sawi bakso & lose weight & 0,1 & 0,65 \\
\hline & Brassica oleracea L. & Kobis & Increase immunity & 0,07 & 0,01 \\
\hline & Brassica olearacea L. & Brokoli & improve the health of bones and teeth, & 0,12 & 0,65 \\
\hline & Nasturtium officinale L. & Cenil & prevent constipation & 0,12 & 0,65 \\
\hline Cactaceae & Hylocereus undatus Haw. & Buah Naga & blood circulation & 0,1 & 0,01 \\
\hline Cannaceae & Canna discolor $\mathrm{L}$. & Ganyong & relieves heartburn symptoms & 0,07 & 0,01 \\
\hline Caricaceae & Carica papayaL. & Kates & Digestion & 0,12 & 1,96 \\
\hline Chenopodiaceae & Beta vulgaris L. & Bit & Lower blood pressure & 0,07 & 2,61 \\
\hline \multirow[t]{2}{*}{ Convolvulaceae } & Ipomoea batatas $\mathrm{L}$. & Telo & Source of carbohydrates, lose weight, & 0,1 & 0,01 \\
\hline & Ipomoea aquatica Forsk. & Kangkung & against liver damage, & 0,17 & 0,01 \\
\hline \multirow[t]{5}{*}{ Cucurbitaceae } & Sechium edule L. & Jepan & mineral source of the body & 0,1 & 0,01 \\
\hline & Cucurbita moshcata Durch. & Pumpkin & Improve the immune system, & 0,07 & 0,01 \\
\hline & Cucumis sativus L. & Timun & Antioxidants, smooth digestion & 0,07 & 0,01 \\
\hline & Momordica charantia L. & Pare & Relieves asthma, fights cancer cells, & 0,1 & 0,65 \\
\hline & Cucumis melo L. & Melon & prevent skin aging & 0,07 & 0,65 \\
\hline Dendrocalamaeae & Dendrocalamus asper L. & Boung & lowering the risk of stroke & 0,07 & 0,65 \\
\hline \multirow[t]{2}{*}{ Dioscoreaceae } & Dioscorea alata $\mathrm{L}$. & Uwi & Lowering blood sugar and cholesterol levels & 0,05 & 0,65 \\
\hline & Dioscorea esculenta L. & Mbili & Prevent diabetes, & 0,07 & 0,65 \\
\hline Ebenaceae & Diospyros kaki L. & Tledung & stop bleeding & 0,07 & 1,96 \\
\hline \multirow[t]{2}{*}{ Euphorbiaceae } & Manihot utillisima Pohl. & Pohung & relieves pain & 0,07 & 3,27 \\
\hline & Euphorbia heterophylla L. & Patik Mas & Reduces swelling due to snake bites & 0,07 & 1,96 \\
\hline \multirow[t]{8}{*}{ Fabaceae } & Clitoria ternatea $\mathrm{L}$. & Telang & contains antioxidants, heal wounds & 0,1 & 0,01 \\
\hline & Glycine $\max \mathrm{L}$. & Dele & Lower blood pressure & 0,07 & 0,01 \\
\hline & Arachis hypogea $\mathrm{L}$. & Kacang Brol & Prevent cancer & 0,07 & 0,65 \\
\hline & Vigna cylindrica $\mathrm{L}$. & $\begin{array}{l}\text { Kacang } \\
\text { Panjang }\end{array}$ & increase immunity & 0,1 & 0,65 \\
\hline & Sesbania grandiflora L. & Turi & Treat coughs, dysentery & 0,1 & 0,01 \\
\hline & Phaseolus vulgaris L. & Buncis & Maintain heart health & 0,07 & 0,01 \\
\hline & Pisum sativum L. & Kapri & Free radical scavenger & 0,07 & 0,65 \\
\hline & Leucaena leucocephala & Metir & eradicate worms, prevent diabetes & 0,07 & 0,65 \\
\hline Gnetaceae & Gnetum gnemon L. & Melinjo & Smooth urine, & 0,1 & 0,65 \\
\hline Graminaceae & Zea mays L. & Jagung & Source of carbohydrates (daily staple food) & 0,02 & 0,01 \\
\hline Lamiaceae & Ocimum sanctum $\mathrm{L}$. & Kemangi & Prevent fever & 0,07 & 0,65 \\
\hline \multirow[t]{2}{*}{ Liliacea } & Allium cepa $\mathrm{L}$. & Brambang & Prevent colds, & 0,1 & 0,65 \\
\hline & Allium sativum $\mathrm{L}$. & Bawang Putih & natural antibiotics & 0,12 & 0,65 \\
\hline
\end{tabular}




\begin{tabular}{|c|c|c|c|c|c|}
\hline Family & Scientific Name & Local Name & Benefits & Uvs & INP \\
\hline & Aloe vera $\mathrm{L}$. & Lidah Buaya & Speed up wound healing, & 0,07 & 0,01 \\
\hline Malvaceae & Abelmoschus esculentus L. & Okra & prevent kidney disorders & 0,07 & 0,01 \\
\hline Marantaceae & Maranta arundinacea $\mathrm{L}$. & Garut & Overcoming digestive diseases & 0,02 & 0,65 \\
\hline \multirow[t]{2}{*}{ Moraceae } & Artocarpus altilis Park. & Sukun & treat gout & 0,07 & 0,65 \\
\hline & $\begin{array}{l}\text { Artocarpus heterophyllus } \\
\text { Lam. }\end{array}$ & Gori & cure insomnia & 0,1 & 0,65 \\
\hline Musaceae & Musa paradisiaca $\mathrm{L}$. & $\begin{array}{l}\text { Gedang } \\
\text { Kepok }\end{array}$ & accelerating the digestive system & 0,07 & 0,65 \\
\hline \multirow[t]{2}{*}{ Myrtaceae } & Psidium guajava $\mathrm{L}$. & Jambu Klutuk & tackle dengue fever & 0,1 & 0,01 \\
\hline & Syzygium aromaticum $\mathrm{L}$ & Cengkeh & Treating stomach ulcers, & 0,1 & 0,01 \\
\hline Pandanaceae & $\begin{array}{l}\text { Pandanus amaryllifolius } \\
\text { Roxb. }\end{array}$ & Pandan & strengthens nerves & 0,12 & 1,96 \\
\hline \multirow[t]{2}{*}{ Phyllanthaceae } & Sauropus androgynus $\mathrm{L}$. & Katu & Smooth out milk production & 0,1 & 1,96 \\
\hline & Phyllanthus niruri $\mathrm{L}$. & Meniran & Cure liver disease & 0,07 & 0,01 \\
\hline Piperaceae & Piper betle L. & Suroh & antiseptic & 0,12 & 0,01 \\
\hline \multirow[t]{2}{*}{ Poaceae } & Oryza sativa $\mathrm{L}$. & Pari & Source of carbohydrates & 0,02 & 5,23 \\
\hline & Cymbopogon citratus L. & Sere & $\begin{array}{l}\text { Antioxidants, control, regulate muscle } \\
\text { function }\end{array}$ & 0,07 & 0,65 \\
\hline Portulaceae & Portula oleracea L. & Krokot & Prevent kidney stones, treat rheumatism & 0,07 & 0,01 \\
\hline \multirow[t]{2}{*}{ Rosaceae } & Rosa $\mathrm{L}$. & Mawar & improves immunity & 0,07 & 0,01 \\
\hline & Fragaria anansa $\mathrm{L}$. & Stoberi & Maintain heart health, prevent allergies & 0,07 & 1,96 \\
\hline Rutaceae & Citrus hystrix D.C & Jeruk Purut & Clean the blood, increase endurance & 0,07 & 1,96 \\
\hline \multirow[t]{5}{*}{ Solanaceae } & Solanum lycopersicum $\mathrm{L}$. & Tomat & maintain eye health, treat acne & 0,12 & 0,65 \\
\hline & Capsicum annum $\mathrm{L}$. & Lombok & $\begin{array}{l}\text { Streamlining bowel movements, treating } \\
\text { thrush, }\end{array}$ & 0,2 & 1,96 \\
\hline & Solanum melongena $\mathrm{L}$. & Terong & Overcoming stomach acid & 0,15 & 2,61 \\
\hline & Solanum tuberosum $\mathrm{L}$. & Kentang & Maintain heart health, antioxidants, & 0,15 & 0,01 \\
\hline & Capsicum annum $\mathrm{L}$. & Paprika & prevent anemia, control blood sugar & 0,07 & 0,01 \\
\hline \multirow[t]{5}{*}{ Zingiberaceae } & Curcuma dosmetica loir & Kunir & Overcoming menstrual problems & 0,17 & 0,65 \\
\hline & Kaempferia galanga $\mathrm{L}$. & Kencur & Treating coughs, treating diarrhea & 0,15 & 0,01 \\
\hline & Zingiber officinale Rosc & Jahe & Strengthens immunity, warms the body & 0,12 & 0,01 \\
\hline & Curcuma zanthorrhiza $\mathrm{L}$. & Temu Lawak & pain reliever, increases milk production & 0,1 & 0,65 \\
\hline & Alpinia galaga $\mathrm{L}$. & Laos & Cure asthma & 0,07 & 0,65 \\
\hline
\end{tabular}

\section{CONCLUSION}

Based on the results and discussion, it can be concluded that the people on the slopes of Mount Merapi and Merbabu use 74 species of plants from 37 families. The most commonly used plants are dominated by the Fabaceae, Zingiberacee and Solanaceae families. The most widely used plants organs were leaves $(29.73 \%)$, fruit $(17.57 \%)$, and tubers (10.81). Based on its use, it has the highest value (29.73\%), followed by direct consumption (10.81\%) and boiled (16.22\%). The method of obtaining food plants by cultivation was in the highest ranking $(72.97 \%)$, followed by buying in the market $(21.62 \%)$ and wild plants $(5.4 \%)$. Plants that have a high use value (Uvs) of fennel with a value of 0.25 , chili pepper 0.20 and turmeric 0,17 . Food plants that are excellent with the highest index of importance value are rice $5.23 \%$, fennel $4.57 \%$ and cassava $3.27 \%$. All the knowledge they have is knowledge acquired from generation to generation.
Acknowledgments: The results of this study involved various parties, many thanks to the people on the slopes of Merapi Merbabu, to be precise, Mliwis village, especially the Baksari and Ngarsapura hamlets who have provided information about local knowledge on food plants and medicines they have, as well as to colleagues who have helped us.

Conflict of interest: The authors declares that there are no conflicts of interest concerning the publication of this article.

\section{REFERENCES}

Anggraini F. (2013). Aplikasi Plasticizer Gliserol Pada Pembuatan Plastik Biodegradable Dari Biji Nangka. Semarang: Jurusan Kimia Fakultas MIPA UNNES.

Astawan M. (2003). Pangan Fungsional untuk Kesehatan yang Optimal. Jakarta: Bumi Aksara. 
Backer, A.C \& Van Den Brink.B.C.R. (1963). Flora of Java (Spermatophytes Only) Vol. I. N.V.P. The Netherlands: Noordhoff-Groningen.

Backer, A.C \& Van Den Brink.B.C.R. (1965). Flora of Java (Spermatophytes Only) Vol. II. N.V.P. The Netherlands: Noordhoff-Groningen.

Backer, A.C \& Van Den Brink.B.C.R. (1968). Flora of Java (Spermatophytes Only) Vol. III. N.V.P. The Netherlands: Noordhoff-Groningen.

Cotton, C.M. (1996). Etnobotany.Principles and Applications. UK John Willey \& Sons Inc London: Roehamton Insitute London.

Efremila, Wardenaar, E, Sisilia L. (2015). Studi Etnobotani Tumbuhan Obat Oleh Etnis Suku Dayak di Desa Kayu Tanam Kecamatan Mandor Kabupaten Landak. Jurnal Hutan Lesatari 3(2): 234-246.

Gunawan, A. (2014). Food combining, makanan serasi pola makan untuk langsing dan sehat. Jakarta: PT. Gramedia Pustaka Utama.

Heyne K. (1987). Tumbuhan berguna Indonesia II. Jakarta: Badan Litbang Kehutanan.

Martin Gj. (1998). Etnobotani: Sebuah Manual Pemeliharaan Manusia dan Tumbuhan (diterjemahkan oleh Maryati Mohamed). Edisi Bahasa Melayu. Malaysia: Natural History Publication (Borneo) Sdn Bhd.

Nahdi MS, Nugraheni, I, dan Arsyah DC, (2016). The Etnobotany of Medical Plants in Supporting the Family health in Turgo, Yogyakarta, Indonesia. Biodiversitas 17 (2): 900-906.

Nahdi, Maizer, Ardyan Pramudya Kurniawan. (2019). The Diversity and Etnobotanical Study of Medicinal Plants in the Southern Slope of Mount Merapi, Yogyakarta, Indonesia. Jurnal Biodiversitas, 20 (8): 2279-2287.

Newall, C., Anderson I, Philipson. J. (1995). Herbal Medicines. The school of Pharmacy University of London: Departemen of Pharmacognosy.
Nita, AB. (2017). Etnobotani Tumbuhan Pangan dan Obat Masyarakat Suku Arfak di Kampung Warmare, Kabupaten Manokwari. Jurnal UAJY: 1-15.

Payung Y.R, Miswan dan Pitopang, R. (2016). Studi Etnobotani Tumbuhan Pangan pada Suku Kaili Ija di desa Bora Kecamatan Sigi Biromaru Kabupaten Sigi Sulawesi Tengah. Biocelebes. 10 (1): 27-44.

Permana.E., Nasution, I.P dan Gunawijaya.J. (2011). Kearifan Lokal Tentang Mitigasi Bencana Pada Masyarakat Baduy. Jurnal Makara 15(1): 67-76.

Savitri, E., S. (2008). Rahasia Tumbuhan Berkhasiat Obat Perspektif Islam. Malang: UIN Press.

Silalahi, M, Nisyawati, Walujo E.B dan Mustaqim W. (2018). Etnomedisin Tumbuhan Obat Oleh Subetnis Batak Phakpak Di Desa Sarung Mersada, Kabupaten Phakpak Bharat, Sumatera Utara. Jurnal Ilmu Dasar 19(2): 77-92.

Sukamto. 2007. Babadotan (Ageratum conyzoides) Tanaman Multi Fungsi. Jurnal Warta Puslitbangbun 13(3).

Sukmawati, N., Eny, Y., Pitopang, R. (2013). Studi Etnobotani Tumbuhan Obat Pada Masyarakat Suku Kaili Rai di Desa Toga Kecamatan Ampibabo Kabupaten Parigi Moutong Sulawesi Tengah.Jurnal Biocelebes, 7(2): 9-16.

Zaman, Q., Hariyanto, S. dan Purnobasuki, H. (2013). Etnobotani Tumbuhan di Kabupaten Sumenep Jawa Timur. Jurnal Matematika dan Ilmu Pengetahuan Alam 16 (1): 21-30.

Zuhdi, AC. (2012). Krisis Lingkungan Hidup Dalam Prespektif Islam. Jurnal Mutawatir 2(2): 140-162.

Zulharman, Z, Yanuwiyadi B, Baroto J. (2015). Etnobotany and Food Plant Community Sambori District Bima Regency West Nusa Tenggara Indonesia. Natural B, Journal of Health and Environmental Sciences 3(2): 198-204. 
THIS PAGE INTENTIONALLY LEFT BLANK 